Editorial

\title{
The case for adopting sustainability goals in ophthalmology
}

Neil Murray FRANZCO, ${ }^{1}$ Heather G Mack PhD FRANZCO ${ }^{2}$ and Salmaan Al-Qureshi FRANZCO 3

1 Rotorua Eye Clinic, Rotorua, 3010, New Zealand

2 Department of Surgery (Ophthalmology), University of Melbourne, Parkville 3010, Australia

3 Centre for Eye Research Australia, East Melbourne 3002, Australia

Heather Mack ORCID 0001-9756-1098

Correspondence: Neil Murray, Rotorua Eye Clinic, PO BOX 47, Rotorua, 3010, New Zealand

Email: nmurray@rotoruaeyes.co.nz

Funding sources / Financial disclosure: None

Conflict of interest: The authors will materially and financially benefit from living on a healthy planet. They therefore disclose a profound conflict of interest.

This is the author manuscript accepted for publication and has undergone full peer review but has not been through the copyediting, typesetting, pagination and proofreading process, which may lead to differences between this version and the Version of Record. Please cite this article as doi: 10.1111/ceo.13607

This article is protected by copyright. All rights reserved. 
In 2018, the scientific proof for human induced climate change exceeded the gold standard - the "5 Sigma" threshold. This standard is equivalent to a randomised control trial with a $p$ value of $=0.0000003$. To be clear, this is a threshold so high that no intervention in medicine has ever, or is likely to ever, meet it. Not penicillin, not laser for proliferative diabetic retinopathy not femtosecond cataract surgery. A recent report concluded that, with current trends, the average global temperature will increase by 1.5 degrees Celsius by 2029. This temperature, which has been determined to be the safe upper limit for our species, will be reached in 11 years. ${ }^{i}$ A former Australian Prime Minister, Tony Abbott, was indeed correct when he stated "... the earth will survive climate change...". There is however no guarantee that our species will.

We have taken oaths to act in the best interest of our patients. We must accept the science and act accordingly, making our medical practice sustainable.

In its broadest sense sustainability can be defined as "... meeting the needs of the present without compromising the ability of future generations to meet their needs....". Sustainability is inextricably linked to good health.iii What are the consequences of not being sustainable? Human existence, as we currently know it, is unsustainable and has been increasingly so for the past fifty years. ${ }^{\text {iv }}$ One measure of this is Earth Overshoot Day. Overshoot Day is the day on which the global annual consumption of resources exceeds the Earth's regenerative capacity for any given year. In 1970 it was December 29. This year, 2019, it is likely to be J uly 29. v Unsustainable consumption is causing global warming. Greenhouse gases (GHGs) act like the windows of a greenhouse, allowing light through but trapping heat inside the atmosphere. GHGs (in particular carbon dioxide) in the atmosphere have increased rapidly in the past 120 years. Human activities - the combustion of fossil fuels - are the primary cause of global warming. 
Carbon foot printing is an assessment of all the GHGs generated by an activity - be it the making, using and disposing of a product or provision of services. The healthcare sector contributes significantly to the carbon footprint of developed world countries. vi In the US, in 2013 , it was responsible for $9 \%$ to $10 \%$ of all GHGs. These were both direct: from health care facilities and vehicles, and in larger part, indirect: from upstream production of electricity, drugs, medical devices and supplies, and other goods and services that feed into the healthcare activities. Hospitals and

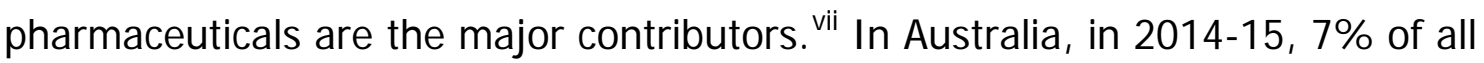
GHGs came from healthcare services. ${ }^{\text {viii }}$

The carbon footprint of a phacoemulsification cataract surgery in the UK has been estimated at $181.8 \mathrm{~kg} \mathrm{CO}_{2} \mathrm{eq}$, comprising procurement $54 \%$, building and energy use $36 \%$ and travel $10 \% .{ }^{i x}$ This is the equivalent footprint of one individual for one week of their life in the developed world.

In addition to GHGs, healthcare associated emissions of several other types of pollutants have been quantified. Public health damages from exposure to non-GHGs emissions is estimated at 405000 disability-adjusted life-years (DALYs) annually. Most of these DALYs were attributable to particulate matter emissions. ${ }^{{ }^{x}}$ These health damages are comparable in magnitude to preventable medical errors. They are incurred indirectly by the general public rather than directly by patients. They are also partially preventable. Circular economics - making sure we can unmake everything we make - not linear economics - take, make, dispose, waste will reduce wasted resources that do not benefit patient outcomes, as well as reduce upstream emissions and their associated damages. ${ }^{\text {xi }}$

The critical finding of The Lancet Commission on Health and Climate Change - that tackling climate change could be the greatest global health opportunity of the 21st century - resulted in several recommendations. They emphasised the need for health professional leadership to help unite stakeholders behind the common cause of public health. 
The United Nations developed and adopted, in 2015, the Sustainable Development Goals (SDGs) as both a call to action, and as a standardised methodology - a lingua franca as it were - to map, measure, report and benchmark sustainability

activities. ${ }^{x i 1}$

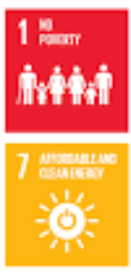

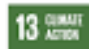
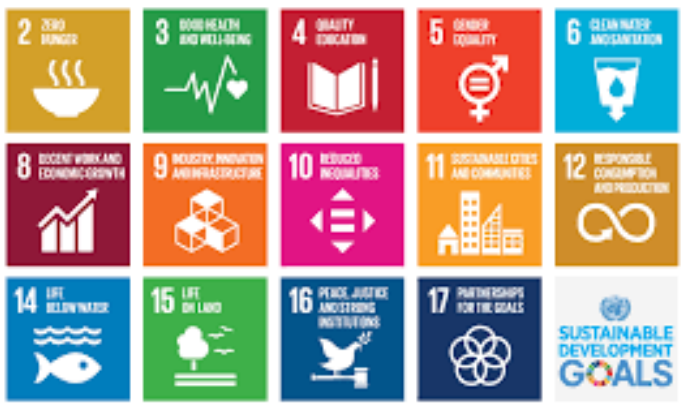

(figure 1) Sustainable Development Goals

The SDG are aimed at all countries, not solely developing countries. They are intended to reduce inequality, improve health and preserve our planet. Australia and New Zealand have committed to implement the SDGs both at home, and as part of their international development and humanitarian assistance programs.

The SDGs are intended to drive organisational thinking. The financial community have responded. Returns for sustainable investments are now on-par with traditional investments. xiii Globally, university rankings now include assessment of impacts against the SDGs. In 2019, The University of Auckland ranked first place in the individual university rankings. Australian universities collectively place third overall globally behind those of Canada and Ireland. ${ }^{\text {xiv }}$

The Australian government released its voluntary national review on achieving the SDGs in 2018, New Zealand in 2019. In the healthcare sector, The Australian and New Zealand Medical Associations are taking leadership and releasing position statements.

The Royal Australian and New Zealand College of Ophthalmologists (RANZCO) - is incorporating the SDGS in its business strategy for 2021-2023. RANZCO is already active across eleven of the seventeen SDGs. The lingua franca of the SDGs will enable RANZCO to more effectively reference and message its activities. It will 
support our social licence, amongst various national and state stakeholders, as the leader in collaborative eyecare.

Individually, ophthalmologists can make meaningful changes. We can consider changes to transport choices and promote the circular economy through recycling and avoiding the throwaway culture. ${ }^{\mathrm{xv}}$

In short, the consequences of being unsustainable are dire. Unchecked, it will ultimately render our planet inhospitable. Any human existence may likely be, as $\mathrm{Dr}$ Spock from Star Trek would say, "... not life as we know it...".

In this generation ophthalmologists need to rise to the challenge. RANZCO should seek to not only be the leader in collaborative eyecare, but the acknowledged leader in sustainable collaborative eyecare. 


\section{REFERENCES}

' (https://report.ipcc.ch/sr15/pdf/sr15 spm final.pdf).

ii World Commission on Environment and Development. Our Common Future. Oxford: Oxford University Press, 1987.

iii Whitmee S, Haines A, Beyrer C et al. The Rockefeller Foundation-Lancet Commission on planetary health. Lancet 2015; 386: 1973-2028.

iv Lin D, Hanscom L, Murthy A et al. Ecological footprint accounting for countries: updates and results of the national footprint accounts, 2012-2018. Resources 2018; 7: 58; doi: $\underline{10.3390 / \text { resources } 7030058}$

v Global Footprint Network. Earth Overshoot Day. Oakland: Global Footprint Network, 2019. Accessed June 2019. Available from: https://www.overshootday.org.

vi https://sustainablehealthcare.org.uk/what-we-do/carbon-footprinting-and-triple-bottomline-analysis

vii Eckelman MJ, Sherman JD. Estimated Global Disease Burden from US Health Care Sector Greenhouse Gas Emissions. Am J Public Health 2018 April; 108(Suppl 2): S120-S122. Published online 2018 April. doi: 10.2105/AJPH.2017.303846

viii Malik A, Lenzen M, McAlister S et al. The carbon footprint of Australian health care. Lancet Planetary Health 2018; 2: e27-35; doi: 10.1016/S2542-5196(17)30180-8

${ }^{i x}$ Morris DS, Wright t, Somner JEA et al. The carbon footprint of cataract surgery. Eye 2013;

27: 495-501.

${ }^{x}$ Eckelman MJ, Sherman JD. Environmental impacts of the US health care system and effects on public health. PLoS One. 2016;11(6): e0157014

xi Brown LH, Buettner PG, Canyon DV. The energy burden and environmental impact of health services. Am J Public Health. 2012;102(12):e76-e82

This article is protected by copyright. All rights reserved. 
xii United Nations. Transforming our World: the 2030 Agenda for Sustainable Development. New York: United Nations, 2017. Accessed June 2019. Available from https://www.un.org/sustainabledevelopment/sustainable-development-goals/

xiii https://responsibleinvestment.org/wpcontent/

uploads/2018/08/RIAA_RI_Renchmark_Report_AUS_2018v8.pdf

xiv Times Higher Education. University Impact Ratings. London: Times Higher Education, 2019.Availablefrom:

https://www.timeshighereducation.com/rankings/impact/2019/overall\#!/page/0/length/25 Lsort by/rank/sort order/asc/cols/undefined

${ }^{\mathrm{xv}}$ Storz MA. A practical guide for physicians and health care workers to reduce their carbon footprint in daily clinical work. Perm J 2018; 22: 17-145.

This article is protected by copyright. All rights reserved. 


\section{University Library}

\section{- M M N E R VA A gateway to Melbourne's research publications}

Minerva Access is the Institutional Repository of The University of Melbourne

Author/s:

Murray, N;Mack, HG;Al-Qureshi, S

Title:

The case for adopting sustainability goals in ophthalmology

Date:

2019-09-01

Citation:

Murray, N., Mack, H. G. \& Al-Qureshi, S. (2019). The case for adopting sustainability goals in ophthalmology. CLINICAL AND EXPERIMENTAL OPHTHALMOLOGY, 47 (7), pp.837-839. https://doi.org/10.1111/ceo.13607.

Persistent Link:

http://hdl.handle.net/11343/286352 